\title{
PENINGKATAN KEMAMPUAN BERPIDATO DI DEPAN KELAS DENGAN MENGGUNAKAN METODE PEMBELAJARAN TERBALIK BAGI SISWA KELAS IX A SMP NEGERI 5 KOTA BENGKULU
}

\author{
ELVI SILISMI \\ SMP Negeri 5 Kota Bengkulu \\ Email : elvisilismi41@guru.smp.belajar.id
}

\begin{abstract}
ABSTRAK
Penelitian ini bertujuan untuk mendeskripsikan apakah penggunaan metode Pembelajaran Terbalik dapat meningkatkan kemampuan berpidato siswa kelas IXA SMP Negeri 5 Kota Bengkulu. Penelitian di laksanakan pada semester genap tahun pelajaran 2020/2021. Subjek penelitian terdiri dari 26 siswa kelas IX A SMP Negeri 5 Kota Bengkulu. Penelitian ini dilatar belakangi oleh rendahnya minat, keaktifan dan kemampuan berpidato siswa di depan kelas. Penelitian tindakan kelas dilaksanakan sebanyak 2 siklus. Tiap siklusnya terdiri dari 4 tahap, yakni perencanaaan, pelaksanaan, observasi, dan refleksi. Instrumen yang digunakan merupakan lembar tes hasil belajar yang di berikan sebelum tindakan/ pratindakan dan setelah tindakan lembar observasi dan lembar kerja kelompok. Pengumpulan data dan pengolahannya berdasarkan data yang didapatkan pada instrumen tersebut. Penggunaan metode Pembelajaran Terbalik dapat meningkatkan kemampuan berpidato di depan kelas siswa kelas IXA SMP Negeri 5 Kota Bengkulu. Peneliti menggunakan pendekatan kualitatif dan kuantitatif. Hasil penelitian menunjukkan bahwa siswa menjadi semakin terampil berpidato di depan kelas dengan bahasa yang baik, benar dan santun. Siswa tampil di depan kelas sudah memperhatikan aspek-aspek berpidato yang baik seperti ketepatan ucapan/lafal, penempatan tekanan/intonasi, pilihan kata, kelancaran berbicara, penguasaan topik,dan kerelevansian. Pada pratindakan jumlah siswa 26 siswa yang tuntas hanya 2 siswa $(07,69 \%$.) Pada siklus 1 siswa yang tuntas 9 siswa $(34,61 \%)$, siswa yang belum tuntas 17 siswa $(65,38 \%)$. Nilai siswa tertinggi 85 , dan nilai siswa terendah 59. Sedangkan pada siklus 2 siswa tuntas 23 siswa $(88,46 \%)$ siswa belum tuntas 3 siswa (11,53\%). rata-rata nilai meningkat dari 69,53 menjadi 85,53 dengan nilai tertinggi 96 sedangkan nilai terendah 78. Dapat disimpulkan bahwa tingkat keberhasilan pada siklus 1 belum berhasil sedangkan pada siklus 2 sudah berhasil. Hal ini berarti, bahwa Metode Pembelajaran Terbalik untuk pembelajaran berpidato di depan kelas siswa kelas IX A SMP Negeri 5 Kota Bengkulu sangat tepat dan berhasil.
\end{abstract}

Kata Kunci: Peningkatan, Kemampuan, Berpidato, Pembelajaran Terbalik

\section{PENDAHULUAN}

Pembelajaran Bahasa Indonesia (PBI) mencakup empat keterampilan berbahasa, yakni keterampilan menyimak, keterampilan berbicara, keterampilan membaca dan keterampilan menulis. Jika seseorang mempunyai keterampilan bahasa tersebut, maka akan lebih mudah mendapatkan informasi dan berkomunikasi dengan orang, baik secara lisan maupun tulisan (Mahardini dkk. 2017). Keempat keterampilan berbahasa tersebut dalam pembelajaran tidak dapat dipisahkan antara keterampilan yang satu dengan keterampilan yang lain, artinya keempat keterampilan berbahasa tersebut dalam pembelajaran saling berkaitan. Keterkaitan keempat keterampilan berbahasa dalam pembelajaran dapat dikaitkan dengan pendapat Nida (dalam Muhammad Ilham dan Wijiati, 2020) yang mengatakan bahwa Keterampilan berbicara sebagai pengantar keterampilan berbahasa. Berbicara merupakan cara seseorang berkomunikasi dengan orang lain untuk menyampaikan sesuatu yang diinginkan. Menyimak dan berbicara merupakan aspek ketrampilan berbahasa ragam lisan, sedangkan membaca dan menulis merupakan keterampilan berbahasa ragam tulis. Menyimak dan membaca merupakan alat untuk menerima korespondensi sedangkan berbicara serta menulis adalah cara untuk mengekpresikan makna.

Bagi sebagian orang mungkin berpendapat bahwa berbicara itu mudah dan tidak memerlukan proses. Namun, berbeda pada posisi resmi dengan berbicara di depan banyak 
orang seperti pidato, memberikan sambutan, bercerita, dan sebagainya. Berbicara di depan banyak orang dengan kondisi yang resmi diperlukan proses belajar, agar memiliki keterampilan berbicara yang baik

Pembelajaran berbicara dapat dikatakan sangat mendukung keberhasilan pembelajaran keterampilan berbahasa yang lain. Tarigan (2015) yang menyatakan keberadaan Pembelajaran berbicara di sekolah pun masih di anak tirikan dan belum diupayakan secara optimal, hanya sebagai pelengkap yang menempel pada mata pelajaran Bahasa Indonesia. Belum adanya analisis khusus keterampilan berbicara memperburuk kemampuan berpidato di Indonesia. Bagaimana guru akan membimbing siswa untuk terampil berbicara jika guru sendiri tidak mengetahui dan tidak memiliki pedoman dalam pembelajaran berbicara yang efesien. Padahal sudah menjadi tanggung jawab guru untuk menentukan tingkat kematangan dan keahlian berbicara para siswanya dalam pengembangan intelektual, sosial, dan emosionalnya.

Keterampilan berbicara merupakan salah satu keterampilan berbahasa yang harus dimiliki siswa, karena kompetensi keterampilan berbicara adalah komponen terpenting dalam tujuan pembelajaran bahasa Indonesia. Pembelajaran bahasa Indonesia diarahkan untuk meningkatkan siswa agar mampu berkomunikasi, baik secara lisan maupun tertulis. Komponen yang paling penting dalam berkomunikasi adalah keterampilan berbicara. Berbicara dengan konsep dasar sebagai alat untuk berkomunikasi ini, pembejaran keterampilan berbicara diharapkan aktif interaktif baik dua arah atau multi arah. Dengan demikian pembelajaran keterampilan berbicara bukan lagi sesuatu yang monoton dan tanpa makna, namun mendapat respon yang aktif dari audien, khususnya keterampilan berpidato di depan kelas. Dalam berpidato, seorang pembicara hendaknya menggunakan bahasa yang baik, benar, santun, dan komunikatif. Dari faktor kebahasaan antara lain: memperhatikan ketepatan ucapan (ketepatan vokal dan konsonan), penempatan tekanan, nada, sendi, dan durasi yang sesuai, pilihan kata (diksi), dan ketepatan sasaran pembicaraan. Sedangkan dari faktor nonkebahasaan, antara lain: sikap yang wajar, tenang dan tidak kaku, pandangan harus diarahkan kepada lawan bicara (audien), gesture dan mimik yang tepat, volume suara, kelancaran, relevansi/penalaran, dan penguasaan topik.

Berpidato merupakan salah satu bagian dari keterampilan berbicara dan salah satu cara meningkatkan kemampuan berpikir dan berkomunikasi (Darmuki \& Hidayati, 2019). Keterampilan berbicara yang diwujudkan dengan memiliki keterampilan berpidato sangat perlu diasah melalui latihan yang cukup dan teratur serta pembelajaran yang terprogram . Untuk dapat menyampaikan pidato yang baik perlu persiapan yang sebaik-baiknya dan perlu latihan yang teratur ( Putriyani P, 2019). Oleh karena itu semakin baik bahasa seseorang, semakin baik pula jalan pikirannya. Orang dapat mengungkapkan buah pikirannya dengan lancar bila penguasaan bahasanya baik. Sebaliknya bila kemampuan berpikir seseorang rendah, bahasa yang diungkapkannya juga amburadul. Berdasarkan pengamatan penulis pembelajaran berpidato di depan kelas siswa kelas IX A SMP Negeri 5 Kota Bengkulu, siswa kurang merespon materi ini. Hal ini dapat dilihat pada saat pembelajaran, mereka malu-malu untuk tampil menyampaikan pidatonya di depan kelas. Selain itu siswa berpidato juga tidak memperhatikan aspek-aspek kebahasaan dan aspek nonkebahasaan. Hal ini dapat juga dilihat dari nilai rata-rata siswa dalam tes pratindakan pada materi keterampilan berpidato, dengan nilai yang sangat rendah. Permasalahan bagi guru untuk menentukan siswa yang mewakili sekolah dalam kegiatan perlombaan pidato, dalam kegiatan IMTAQ rutin setiap hari Jum,at, wali kelas kesulitan untuk menunjuk siswa yang akan berpidato/berceramah sebagai petugas IMTAQ dari kelasnya, dan juga dengan sulitnya guru menunjuk siswa untuk menyampaikan pidato kata sambutan mewakili kelas IX dalam acara perpisahan sekolah.

Berdasarkan uraian di atas, peneliti berasumsi bahwa dengan menggunakan Metode Pembelajaran Terbalik pada siswa kelas IX A SMP Negeri 5 Kota Bengkulu dapat meningkatkan keterampilan berbicara, khususnya kemampuan berpidato di depan kelas. Berdasarkan latar belakang masalah di atas, rumusan masalah dalam penelitian ini adalah 
bagaimanakah peningkatan kemampuan pidato di depan kelas dengan menggunakan metode Pembelajaran Terbalik siswa kelas IX A SMP Negeri 5 Kota Bengkulu?

Tujuan penelitian ini untuk mengetahui peningkatkan kemampuan Pidato di Depan Kelas dengan menggunakan metode Pembelajaran Terbalik siswa kelas IX A SMP Negeri 5 Kota Bengkulu. Ruang lingkup penelitian ini meliputi dua faktor, yaitu fakor kebahasaan: ketepatan ucapan, penempatan tekanan suara, pilihan kata, sedangkan nonkebahasaan: kelancaran, penguasaan topik, dan relevansi. Penelitian ini diharapkan bermanfaat dalam dunia pendidikan dan pengembangan ilmu kebahasaan agar terus kreatif dalam menerapkan metode Pembelajaran Terbalik yang dapat dijadikan sebagai alternatif dalam pembelajaran pidato. Selain itu, dapat menjadi bahan masukan dan referensi peneliti lain dalam pengkreatifan metode Pembelajaran Terbalik di dunia pendidikan. Bagi Peneliti diharapkan dapat memberikan gambaran tentang pembelajaran khususnya pada kemampuan Pidato dan dapat mengetahui kesulitan-kesulitan yang dialami oleh siswa dalam menyampikan pidato di depan kelas dengan etika yang baik dan santun. Selain itu juga, peneliti dapat mengetahui tingkat keefektifan metode pembelajaran yaitu metode Pembelajaran Terbalik pada pembelajaran keterampilan pidato siswa kelas IX A SMP Negeri 5 Kota Bengkulu. Manfaat praktis, bagi siswa dapat menambah keberanian dan kepercayaan diri dalam menyampaikan suatu informasi dalam bentuk pidato sesuai dengan fakta dan dapat memberikan pengetahuan yang lebih luas, aktual, berpikir kritis dan pengalaman baru terhadap siswa lain. Bagi guru, Penelitian ini dapat menjadi masukan bagi guru Bahasa Indonesia dalam pemilihan dan penerapan metode pembelajaran yang lebih efektif dan menyenangkan, sehingga siswa dapat mengikuti pelajaran dengan baik. Bagi sekolah Hasil penelitian ini dapat memberikan arah kinerja pimpinan sekolah dalam memfasilitasi guru untuk penerapan metode Pembelajaran Terbalik dalam pelaksanaan pembelajaran pidato di depan kelas.

\section{METODE PENELITIAN}

Jenis penelitian yang digunakan adalah Penelitian Tindakan Kelas (PTK). Penelitian tindakan merupakan penelitian dalam bidang sosial, yang menggunakan refleksi diri sebagai metode utama, dilakukan oleh orang yang terlibat di dalamnya, serta bertujuan untuk melakukan perbaikan dalam berbagai aspek. Penelitian tindakan kelas merupakan bentuk penelitian tindakan yang diterapkan dalam aktivitas pembelajaran di kelas (Muhadi, 2011). Penelitian tindakan kelas ditujukan untuk mencari faktor-faktor yang mungkin menghambat atau memperlancar tindakan itu, khususnya yang terjadi pada pembelajaran dikelas. Penelitian ini ditujukan sebagai upaya dalam peningkatan kemampuan berpidato siswa di depan kelas. Tindakan yang akan dilakukan adalah pemanfaatan metode Pembelajaran Terbalik dalam berpidato di depan kelas.

Prosedur penelitian ini dilakukan dalam siklus yang terdiri dari empat tahap, yaitu: (1) Tahap Perencanaan (planning), 2. Tahap Tindakan (acting), (3) Tahap pengamatan (observing), dan (4) Tahap refleksi (reflecting). Secara rinci prosedur penelitian tindakan ini dapat dilihat pada bagan sebagai berikut: 


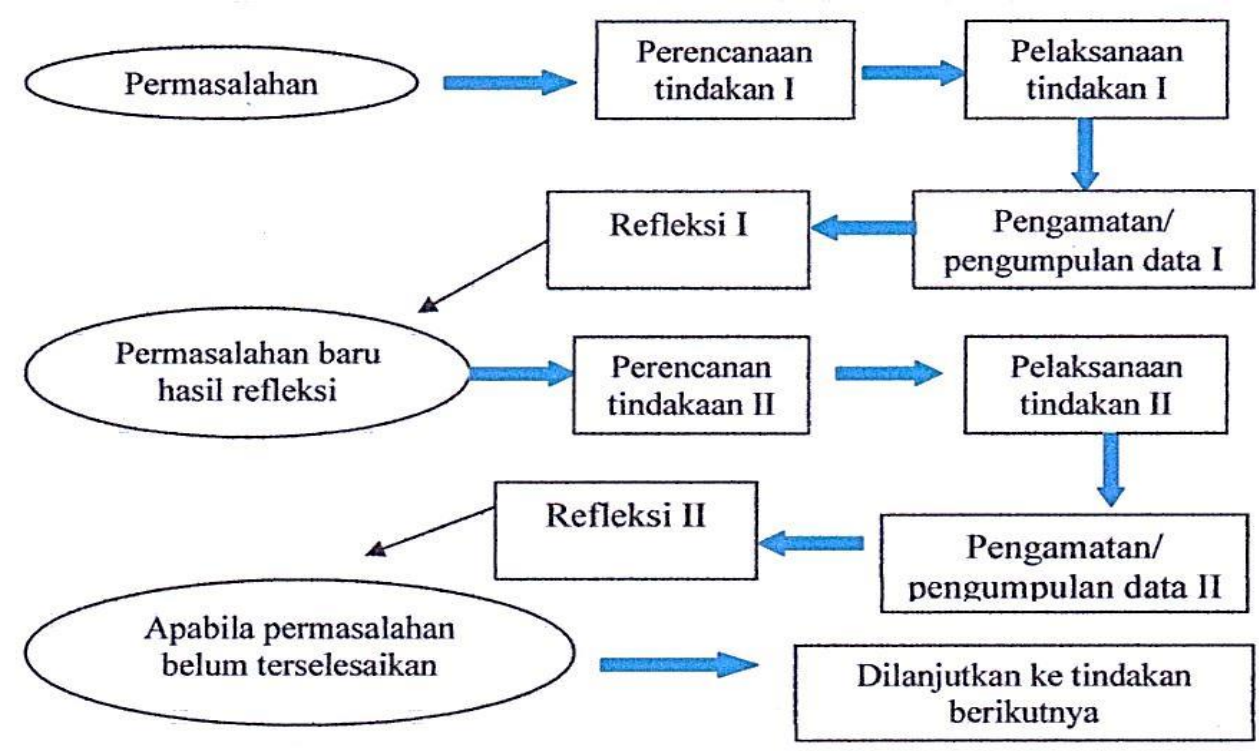

Bagan 1. Alur Penelitian Tindakan Kelas

(Suhardjono dalam Arikunto, dkk., 2012)

Data penelitian ini dikumpulkan dengan metode tes dan observasi. Metode tes digunakan untuk mendapatkan data penelitian melalui penyampaian sejumlah pertanyaan atau tes. Hal ini bahwa tes adalah "serentetan pertanyaan atau latihan serta alat lain yang digunakan untuk mengukur keterampilan pengetahuan intelegensi, kemampuan atau bakat yang dimiliki oleh individu atau kelompok." Penggunaan tes ini dimaksudkan untuk mendapatkan data berupa nilai yang akan menunjukkan bagaimana tingkat penguasaan siswa tentang berpidato. Tes yang dimaksud di sini adalah tes berpidato. Observasi/pengamatan dengan menggunakan lembar observasi siswa dan lembar observasi guru. Teknik analisis data menggunakan triangulasi data.

Metode penelitian yang diggunakan yakni metode deskriptif kuantitatif dan kualitatif. Sukmadinata ( dalam Ade, Candra dan Febsri S, 2019) penelitian deskriptif adalah suatu metode yang ditujukan untuk menggambarkan fenomena-fenomena yang ada, yang berlangsung pada saat ini atau saat yang lampau. Penelitian kuantitatif merupakan data penelitian yang berbentuk angka atau data kuantitaif yang diinginkan atau scoring (Sugiyono, 2013). Penelitian deskriptif kuantitaif merupakan pengumpulan dan pengukuran data yang berbentuk deskripsi dan angka.. Data terkumpul secara deskriptif kuantitatif digunakan untuk memberikan gambaran terhadap keadaan yang sebenarnya, juga untuk menjawab pertanyaan yang berhubungan dengan status subjek dari penelitian. Sedangkan data kualitatif digunakan untuk memperkuat dan melengkapi data secara keseluruhan.

\section{HASIL DAN PEMBAHASAN}

Penelitian ini dilakukan di kelas IX A SMP Negeri 5 Kota Bengkulu tahun pelajaran 2020/2021. Siswa IX A berjumlah 26 orang, terdiri dari 19 siswa perempuan dan 7 siswa lakilaki. Siswa-siswi IX A memiliki kemampuan Pidato yang belum terlalu baik dan mempunyai sifat yang beragam ketika Pidato di depan kelas, ada yang diam saja, malu-malu, tertawa-tawa, melakukan hal lain dan membaca catatannya di depan kelas. Meskipun demikian beberapa siswa di kelas IX A juga ada yang antusias memperlihatkan ketertarikan untuk belajar, aktif bertanya, dan siap untuk belajar. 


\section{Hasil Penelitian \\ Laporan Siklus 1}

Dalam melakukan siklus pertama ada beberapa hal yang harus diperhatikan antara lain: Kegiatan perencanaan tindakan dimulai dengan merencanakan persiapan tindakan. Dalam penelitian ini, peneliti dan observer membahas tentang keterampilan berpidato, maka materi yang digunakan juga berkaitan dengan keterampilan berpidato pada tataran kemampuan berbahasa yang Standar Kompetensi: Mengungkapkan pikiran, perasaan, dan informasi dalam pidato dan diskusi. Kompetensi dasar: Berpidato/berceramah/berkhotbah dengan intonasi yang tepat dan artikulasi yang jelas.

Rencana Pelaksanaan Tindakan (RPP) disusun secara kolaborasi antara peneliti sebagai guru mata pelajaran Bahasa Indonesia di kelas IX A dan teman sejawat sebagai observer. Skenario pembelajaran dibuat oleh peneliti. Skenario ini berisi rincian kegiatan yang dilakukan guru dalam pembelajaran disertai waktunya. Hal ini bertujuan agar tidak ada kegiatan terlewatkan dan waktu yang dialokasikan dapat dimanfaatkan dengan baik sehingga tidak terjadi kekurangan waktu.

Peneliti membuat lembar observasi yang di dalamnya terdapat gambaran tentang proses guru mengajar dan kondisi aktivitas siswa dalam kegiatan pembelajaran berlangsung, khususnya penerapan metode Pembelajaran Terbalik. Perencanaan ini dilakukan guna terlaksananya penerapan metode Pembelajaran Terbalik pada keterampilan pidato. Mulai dari pemilihan waktu, materi, media, metode yang digunakan sehingga kegiatan belajar mengajar berjalan dengan lancar.

Penelitian pada siklus 1 dilaksanakan 2 kali pertemuan. Pertemuan pertama pada hari Selasa, 12 Januari 2021 dengan alokasi waktu 3 jam atau 120 menit mulai dari pukul 08.50 sampai 09.30 WIB jam ke-3 dan pukul 10.00-11.20 WIB jam ke-4 dan 5. pertemuan kedua dilaksanakan hari Kamis, 14 Januari 2021 dengan alokasi waktu 3 jam atau 120 menit mulai dari pukul 07.30 sampai 09.30 WIB. Jam pertama sampai jam ketiga. Penelitian tindakan kelas ini dilaksanakan oleh Elvi Silismi sebagai guru Bahasa Indonesia dan Ibu Osnawati, M. Pd. sebagai observer. Seluruh siswa hadir pada hari itu yaitu sebanyak 26 siswa terdiri 19 siswa perempuan dan 7 siswa laki-laki di kelas IX A SMP Negeri 5 Kota Bengkulu.

Selama kegiatan belajar pada siklus 1 berlangsung, diadakan observasi oleh teman sejawat sekaligus sebagai observer, untuk melihat tindakan-tindakan guru dan aktivitas siswa dalam pembelajaran berpidato di depan kelas dengan menggunakan metode Pembelajaran Terbalik. Berdasarkan hasil observasi yang didapat bahwa proses belajar mengajar yang telah berlangsung sudah cukup sesuai dengan rencana pembelajaran yang telah disusun dan masih terdapat beberapa kegiatan yang belum terlaksana dengan baik, sehingga masih perlu untuk ditinjau ulang dan diperbaiki untuk direfleksikan. Observasi dilakukan sejak awal proses pembelajaran dimulai sampai akhir proses pembelajaran.

Ketika memasuki kegiatan pembelajaran inti siswa terlihat fokus dan tertarik terhadap pembelajaran. Siswa mulai sedikit tenang ketika guru mulai menjelaskan mengenai metode Pembelajaran Terbalik yang akan digunakan siswa untuk berpidato. Guru sekaligus sebagai peneliti menjelaskan dengan baik materi pembelajaran dan metode pidato yang akan digunakan, serta siswa dibentuk menjadi berkelompok. Guru sebelumnya menyampaikan kepada siswa mengenai aspek penilaian pidato, setelah itu guru berkeliling mengawasi siswa dua kali dan berikutnya guru hanya memantau kegiatan siswa dari tempat duduk (meja guru). Siswa berlatih berpidato di dalam kelompoknya, dengan cara saling membimbing, saling memotivasi, dan bekerja sama. Setelah berlatih di dalam kelompok dengan bimbingan teman sebaya, berikutnya siswa diberi kesempatan untuk menyampaikan pidatonya secara bergiliran. Semua siswa diberi kesemptan untuk menyampaikan pidatonya. Metode menyampaikan pidato di depan kelas sesuai dengan metode yang telah ditetapkan guru/peneliti.

Pada bagian penutup, guru memberikan kesempatan kepada siswa untuk menyampaikan apa yang telah mereka dapat dari materi yang baru saja mereka pelajari. Selanjutnya, guru memberi tugas kepada siswa untuk berlatih lagi dirumah dengan metode pidato yang lain, agar 
pada pertemuan berikutnya mereka mengalami pengalaman baru dengan menggunakan metode pidato yang lain. Kegiatan penutup siswa diberi kesempatan untuk menyampaikan kesan dalam kegiatan pembelajaran yang mereka alami.

Refleksi, kegiatan pembelajaran sudah dilakukan dengan cukup baik, sesuai dengan Rencana Pelaksanaan Pembelajaran (RPP) yang telah direncanakan dan disusun sebelumnya. Pada kegiatan penutup guru mereview materi yang telah dipelajari, dan memberikan penguatan kepada siswa. Siklus 1 dilaksanakan sebanyak dua kali pertemuan. Dari hasil refleksi siklus 1, maka penelitian ini akan dilanjutkan ke siklus II.

Sama seperti pada siklus I, penelitian pada siklus II juga mengikuti skenario yang sudah disusun sebelumnya dan pada siklus II ini akan memperbaiki kekurangan-kekurangan yang ada pada siklus I, setelah dilakukan diskusi atau pembahasan dengan teman sejawat sebagai observer. Sebelum melaksanakan kegiatan siklus II, peneliti sebagai guru Bahasa Indonesia dan dibantu teman sejawat sebagai observer melakukan perencanaan terlebih dahulu agar kegiatan berjalan lancar seperti perencanaan tindakan kelas pada siklus I.

Perencanaan penelitian tindakan kelas siklus II sebagai berikut: Waktu Penelitian tindakan kelas siklus II akan dilaksananakan di kelas IX A SMP Negeri 5 Kota Bengkulu. Penelitian ini akan dilaksanakan sebanyak 2 pertemuan. Pertemuan pertama dilaksanakan pada hari Selasa, 19 Januari 2021. Kegiatan ini dimulai pada pukul 08.50-09.30 WIB jam ke-3 dan pukul 10.00-11.20 WIB jam ke-4 dan 5 atau 3 jam mata pelajaran (120 menit), pertemuan kedua dilaksanakan pada hari Kamis, 21 Januari 2021, kegiatan ini dimulai pada pukul 07.30-09.30 WIB yaitu jam pertama sampai jam ketiga.

Dalam menentukan materi pembelajaran Standar kompetensi yang digunakan pada siklus II sama dengan Standar Kompetensi yang digunakan pada siklus I, yaitu Mengungkapkan pikiran, perasaan, dan informasi dalam pidato dan diskusi. Kompetensi dasarnya adalah Berpidato/berceramah/berkhotbah dengan intonasi yang tepat dan artikulasi serta volume suara yang jelas.

Rencana Pelaksanaan Pembelajaran (RPP) disusun secara kolaborasi antara peneliti sebagai guru mata pelajaran Bahasa Indonesia kelas IX A dengan Ibu Osnawati, M.Pd. sebagai teman sejawat sekaligus sebagai observer. Dalam RPP diuraikan kegiatan-kegiatan yang akan dilaksanakan dalam kegiatan pembelajaran.

Skenario pembelajaran dibuat oleh peneliti sebagai guru mata pelajaran bahasa Indonesia kelas IX A bersama Ibu Osnawati, M.Pd. sebagai observer. Skenario berisi rincian kegiatan yang akan dilakukan guru dalam kegiatan belajar mengajar disertai dengan alokasi waktunya agar kegiatan dapat dimanfaatkan dengan baik sehingga tidak ada kekurangan atau kelebihan waktu.

Kegiatan pembelajaran pada siklus II merupakan refleksi dari siklus I, kegiatan-kegiatan atau pelaksanaan yang masih kurang pada siklus I diperbaiki pada siklus II sehingga pembelajaran dapat bertambah baik. Selama kegiatan pembelajaran berlangsung peneliti dan teman sejawat sebagai observer melakukan observasi sejak awal proses pembelajaran. Observer mengamati tindakan-tindakan guru dan aktivitas siswa, tujuannya untuk melihat apakah kegiatan pembelajaran berpidato di depan kelas sudah sesuai dengan Rencana Pelaksanaan Pembelajaran (RPP) dan skenario pembelajaran.

Seperti yang diharapkan, pada pelaksanaan siklus 2 ini guru telah melaksanakan pembelajaran dengan sangat baik. Beberapa kekurangan yang terdapat pada siklus 1 telah diperbaiki oleh guru sekaligus peneliti. Guru telah melaksanakan proses pembelajaran sesuai dengan RPP dan skenario pembelajaran. Pengaturan waktu juga lebih efisien. Pada kegiatan awal pembelajaran guru telah melakukan apersepsi dengan sangat baik dengan menceritakan pengalaman guru/peneliti ketika berpidato menyampaikan kata sambutan dalam arisan RT dan pengalaman guru/peneliti saat menjadi pembina upacara. Cerita pengalaman tersebut menarik perhatian siswa untuk mengikuti kegiatan pembelajaran. Guru juga membangkitkan motivasi siswa untuk mengikuti kegiatan pembelajaran. Hal ini terlihat dari beberapa siswa yang sebelumnya terlihat acuh, kemudian memperlihatkan keinginan untuk mengikuti kegiatan 
pembelajaran. Guru bertanya kepada siswa tentang siapa yang telah melakukan pidato sebelumnya. Ada dua orang siswa yang telah melakukan pidato, siswa 1 berpidato saat mengikuti lomba pidato dan siswa 2 sudah melakukan pidato saat bertugas sebagai pengisi materi IMTAQ rutin setiap hari Jum'at. Guru menyuruh siswa tersebut untuk menyampaikan informasi dan pengalaman mereka saat berpidato di depan orang banyak.

Meskipun ada siswa yang tertawa ketika siswa yang lain berpidato saat mereka latihan di dalam kelompok dengan bibingan teman sebaya, sehingga keadaan kelas menjadi ribut, namun guru dapat mengondisikan siswa agar tetap tertib dan aktif bermanfaat. Guru menjadi lebih tegas dengan mengatur tekanan suaranya. Dengan pengaturan tekanan suara yang dilakukan guru dapat menarik perhatian siswa. Sebelum siswa menyampaikan pidato di depan kelas, guru menjelaskan terlebih dahulu mengenai aspek penilaian yang akan digunakan ketika siswa pidato di depan kelas. Hal ini dilakukan agar siswa lebih fokus dengan apa yang akan mereka lakukan saat berpidato di depan kelas nanti.

Setelah anggota kelompok menyampaikan pidato di depan kelas secara bergiliran selesai, kelompok lain memberikan tanggapan dengan bimbingan guru agar tidak terjadi keributan akibat mempertahankan pendapat mereka masing-masing. Guru memberikan motivasi kepada siswa mengenai penampilan mereka ketika berpidato di depan kelas. Selanjutnya guru memberi kesempatan kepada siswa untuk melakukan refleksi terhadap pembelajaran yang sudah mereka alami, siswa di minta untuk menyampaikan kesan dari pengalaman belajar mereka. Guru memberikan penguatan terhadap pendapat siswa tersebut.

Kegiatan guru saat melakukan kegiatan belajar mengajar sudah dilakukan dengan cukup baik, sesuai dengan Rencana Pelaksanaan Pembelajaran (RPP) yang telah direncanakan dan disusun sebelumnya. kreativitas siswa juga telah menunjukkan perkembangan yang baik. Siswa dapat menyelesaikan tugas tepat waktu, saat berlatih di dalam kelompok siswa saling membimbing, saling memotivasi, dan saling bekerjasama, siswa menyimak dengan baik ketika anggota kelompok lain menyampaikan pidato di depan kelas. Siswa lebih fokus dalam pembelajaran dengan sikap yang lebih baik.

\section{Pembahasan \\ Siklus 1}

\section{a. Nilai Rata-Rata}

Siklus 1 belum menunjukkan keberhasilan belajar. Berdasarkan penilaian hasil belajar, masih banyak siswa yang belum mencapai KKM yang ditetapkan. Berdasarkan pelaksanaan dan hasil belajar siswa siklus 1 nilai rata-rata yang diperoleh oleh siswa adalah 69,53. Nilai ini diperoleh dari jumlah nilai siswa keseluruhan yaitu 1808 dibagi dengan jumlah siswa yaitu 26 orang. Nilai ini masih dikategorikan cukup. Hal ini dapat dilihat dari perhitungan berikut:

$$
\begin{aligned}
& \dot{\mathrm{X}}=\frac{\sum x}{N}=\frac{\text { jumlah nilai siswa }}{\text { jumlah siswa }} \\
& \dot{\mathrm{X}}=\frac{1808}{26} \\
& \dot{\mathrm{X}}=69,53
\end{aligned}
$$

\section{b. Persentase Ketuntasan Belajar Klasikal}

Hasil tes Pidato berdasarkan kegiatan pembelajaran yang telah dilakukan dengan menerapkan metode Pembelajaran Terbalik menunjukkan bahwa dari 26 siswa yang mengikuti pelaksanaan pembelajaran, hanya 9 orang siswa yang mampu mencapai nilai tuntas, 17 orang belum mampu mencapai nilai tuntas yaitu 80. Ketuntasan belajar klasikal siswa diperoleh hasil $34,61 \%$ siswa yang mampu tuntas belajar secara klasikal. Perolehan ini didapat dari perhitungan jumlah siswa yang mendapat nilai tuntas dibagi jumlah seluruh siswa yang mengikuti pembelajaran di kelas dikali seratus persen. Hal ini dapat dilihat pada perhitungan berikut:

$$
\mathrm{KB}=\frac{N S}{S} X 100 \%
$$




$$
\begin{aligned}
& =\frac{\text { Jumlah siswa yang menadapat nilai } \geq 80}{\text { Jumlah siswa }} \times 100 \% \\
& =\frac{9}{26} \times 100 \% \\
& =34,61 \%
\end{aligned}
$$

\section{c. Daya Serap Klasikal}

Penerapan metode pengajaran terbalik sudah dilaksanakan cukup baik sehingga kualitas pembelajarannya bisa dikategorikan cukup walaupun masih terdapat kekurangan-kekurangan. Hal ini dapat dilihat dari daya serap klasikal yang diperoleh siswa yaitu 69,53\%. Data tersebut diperoleh dari jumlah seluruh nilai siswa yaitu 1808 dibagi dengan jumlah siswa yaitu 26 yang telah dikali sebelumnya dengan jumlah skor ideal yaitu 100, kemudian dikali seratus persen.

$$
\begin{aligned}
\text { DS } & =\frac{\text { Ns }}{\text { S.NI }} \times 100 \% . \\
& =\frac{\text { Jumlah nilai seluruhnya }}{\text { jumlah siswa.jumlah skor ideal }} \times 100 \% . \\
& =\frac{1808}{26.100} \times 100 \% \\
& =69,53 \%
\end{aligned}
$$

Nilai akhir yang diperoleh siswa dikatakan telah mengalami peningkatan apabila kemampuan Pidato siswa secara klasikal telah mendapat nilai baik (75-100). Ketuntasan belajar siswa secara klasikal telah mencapai $80 \%$ ke atas dengan rata-rata nilai kelas lebih dari 80 . Hal ini berarti tujuan pembelajaran masih belum tercapai dan terpenuhi pada siklus 1 .

\section{Siklus 2}

\section{a. Nilai Rata-Rata}

Prosedur tindakan siklus II sama dengan yang dilakukan pada siklus I, hanya lebih ditekankan pada penyempurnaan dari hasil tindakan siklus I. Pada siklus 2 nilai rata-rata siswa mengalami peningkatan yang cukup tinggi dibandingkan dengan siklus 1. Berdasarkan penilaian hasil belajar siswa dengan menggunakan aspek penilaian yang telah ditentukan maka diperoleh nilai rata-rata yang diperoleh oleh siswa sebesar 85,53. Hasil ini diperoleh melalui perhitungan jumlah nilai keseluruhan siswa sebesar 2224 dibagi jumlah siswa yang mengikuti kegiatan pembelajaran sebanyak 26 siswa. Perhitungan tersebut dapat dilihat sebagai berikut: $\dot{\mathrm{x}}$ $=\frac{\sum x}{N}$

$$
\begin{aligned}
& =\frac{\text { jumlah nilai siswa }}{\text { jumlah siswa }} \\
\dot{\mathrm{X}} & =\frac{2224}{26} \\
\dot{\mathrm{X}} & =85,53
\end{aligned}
$$

Pada siklus 1 rata-rata nilai yang diperoleh siswa sebesar 69,53. Dibandingkan dengan siklus 2 yang berjumlah 85.53, maka rata-rata nilai berpidato siswa pada siklus 2 mengalami peningkatan sebanyak 16,00\%. Hal ini sangat baik melihat dari 26 siswa 23 siswa telah berhasil mencapai nilai ketutasan 80 dengan nilai tertinggi 96.

\section{b. Persentase Ketuntasan Belajar Klasikal}

Berdasarkan pelaksanaan dan penilaian hasil belajar siswa siklus 2 menunjukkan bahwa dari 26 siswa yang mengikuti pelaksanaan pembelajaran, 23 siswa mampu mencapai nilai 
tuntas, 3 siswa belum mampu mencapai nilai tuntas. Keempat siswa tersebut belum mencapai nilai tuntas yaitu 80 .

Persentase ketuntasan belajar klasikal siswa adalah 88,46\%. Hasil ini diperoleh berdasarkan perhitungan jumlah siswa yang mendapat nilai tuntas, yaitu 23 siswa dibagi jumlah siswa yang mengikuti kegiatan pembelajaran yaitu 26 siswa dikali seratus persen. Hal ini dapat dilihat pada perhitungan berikut:

$$
\begin{aligned}
\mathrm{KB} & =\frac{N S}{S} \times 100 \% \\
& =\frac{\text { Jumlah siswa yang menadapat nilai } \geq 80}{\text { Jumlah siswa }} \times 100 \% \\
& =\frac{23}{26} \times 100 \% \\
& =88,46 \%
\end{aligned}
$$

Persentase ketuntasan belajar klasikal siswa berdasarkan kriteria perhitungan persentase skor yang diperoleh siswa (Sudijono, 2008:35) dapat dikategorikan baik sekali karena memperoleh nilai $88,46 \%$. Rata-rata semua siswa telah memperoleh nilai rata-rata 80 ke atas. Perhitungan ini lebih tinggi 53,85\% dibandingkan siklus 1 yang memperoleh nilai ketuntasan belajar klasikal 34,61\%. Hal ini menunjukkan bahwa penelitian tindakan kelas telah berhasil karena telah mencapai indikator keberhasilan lebih dari $80 \%$ dan mengalami peningkatan.

\section{c. Daya Serap Klasikal}

Daya serap klasikal yang diperoleh siswa pada siklus 1 sebesar 85,53\%. Hasil ini diperoleh berdasarkan perhitungan jumlah nilai seluruh siswa sebesar 2224 dibagi jumlah siswa sebanyak 26 siswa yang telah dikalikan sebelumya dengan jumlah skor ideal yaitu 100, lalu hasilnya dikali dengan seratus persen. Perhitungan tersebut dapat dilihat sebagai berikut:

$$
\begin{aligned}
& \text { DS }=\frac{\text { Ns }}{\text { S.NI }} \times 100 \% . \\
& =\frac{\text { Jumlah nilai seluruhnya }}{\text { jumlah siswa.jumlah skor ideal }} \times 100 \% . \\
& =\frac{2224}{26.100} \times 100 \% . \\
& =85,53 \%
\end{aligned}
$$

Daya serap klasikal siswa terhadap pembelajaran berpidato mengalami peningkatan dibandingkan dengan siklus 1 yang memperoleh hasil sebanyak 69,53\%. Pada siklus 2 siswa memperoleh hasil daya serap klasikal sebesar 85,53\%. Hal ini memperlihatkan peningkatan daya serap klasikal sebanyak 16,00\%. Berdasarkan perhitungan-perhitungan yang telah dilakukan dapat disimpulkan bahwa siswa telah mencapai indikator keberhasilan dalam penelitian ini dengan memperoleh nilai ketuntasan di atas $80 \%$, yaitu sebesar $88,46 \%$ dengan nilai rata-rata yang diperoleh siswa di atas standar yang ditetapkan yaitu 80 . Nilai rata-rata yang diperoleh siswa sebesar 85,53 dengan 23 siswa yang memperoleh nilai $\geq 80$ dan 3 yang belum mencapai nilai ketuntasan 80 .

Perhitungan tersebut memperlihatkan keberhasilan Penelitian Tindakan Kelas pada kemampuan berpidato di depan kelas dengan menggunakan metode Pembelajaran Terbalik. Siswa telah memperlihatkan peningkatan. Tidak hanya dalam aktivitas belajar namun juga dapat dilihat dari hasil belajar, sehingga penelitian ini tidak perlu dilanjutkan dan berhenti pada siklus 2 . 
Secara umum, selama dilakukan Penelitian Tindakan Kelas dalam pembelajaran meningkatkan kemampuan pidato siswa, menunjukkan adanya peningkatan yang terjadi pada pelaksanaan pembelajaran dan hasil belajar siswa. Berdasarkan pelaksanaan siklus 1 dan siklus 2 telah menunjukkan terjadinya perbaikkan proses dan hasil pembelajaran. Hal tersebut dapat dilihat pada tabel berikut:

Tabel 1. Rekapitulasi Nilai Siswa dalam Pembelajaran Berpidato di Depan Kelas dengan Menggunakan Metode Pembelajaran Terbalik Siklus 1 dan Siklus 2

\begin{tabular}{|l|l|l|l|l|l|l|}
\hline Kondisi & $\begin{array}{l}\text { Jumlah } \\
\text { Peserta }\end{array}$ & $\begin{array}{l}\text { Jumlah } \\
\text { Tuntas }\end{array}$ & $\begin{array}{l}\text { Jumlah } \\
\text { Belum } \\
\text { Tuntas }\end{array}$ & Rata-rata & $\begin{array}{l}\text { Nilai } \\
\text { Tertinggi }\end{array}$ & $\begin{array}{l}\text { Nilai } \\
\text { Terendah }\end{array}$ \\
\hline Pratindakan & 26 & 2 & 24 & 61,42 & 80 & 52 \\
\hline Siklus 1 & 26 & 9 & 17 & 69,53 & 85 & 59 \\
\hline Siklus 2 & 26 & 23 & 3 & 85,53 & 96 & 78 \\
\hline
\end{tabular}

Dari tabel dapat dilihat hasil analisis data, yaitu rata-rata kemampuan berpidato siswa mengalami peningkatan. Pada pratindakan siswa yang tuntas 2 siswa $(07,69 \%)$. Pada siklus I: Siswa yang tuntas 9 siswa $(34,61 \%)$, siswa yang belum tuntas 17 siswa $(65,38 \%)$. Nilai siswa tertinggi 85, dan nilai siswa terendah 59. Sedangkan pada siklus 2: Siswa tuntas 23 siswa $(88,46 \%)$, siswa belum tuntas 3 siswa. rata-rata nilai meningkat dari 69,53 menjadi 85,53 dengan nilai tertinggi 96 sedangkan nilai terendah 78 .

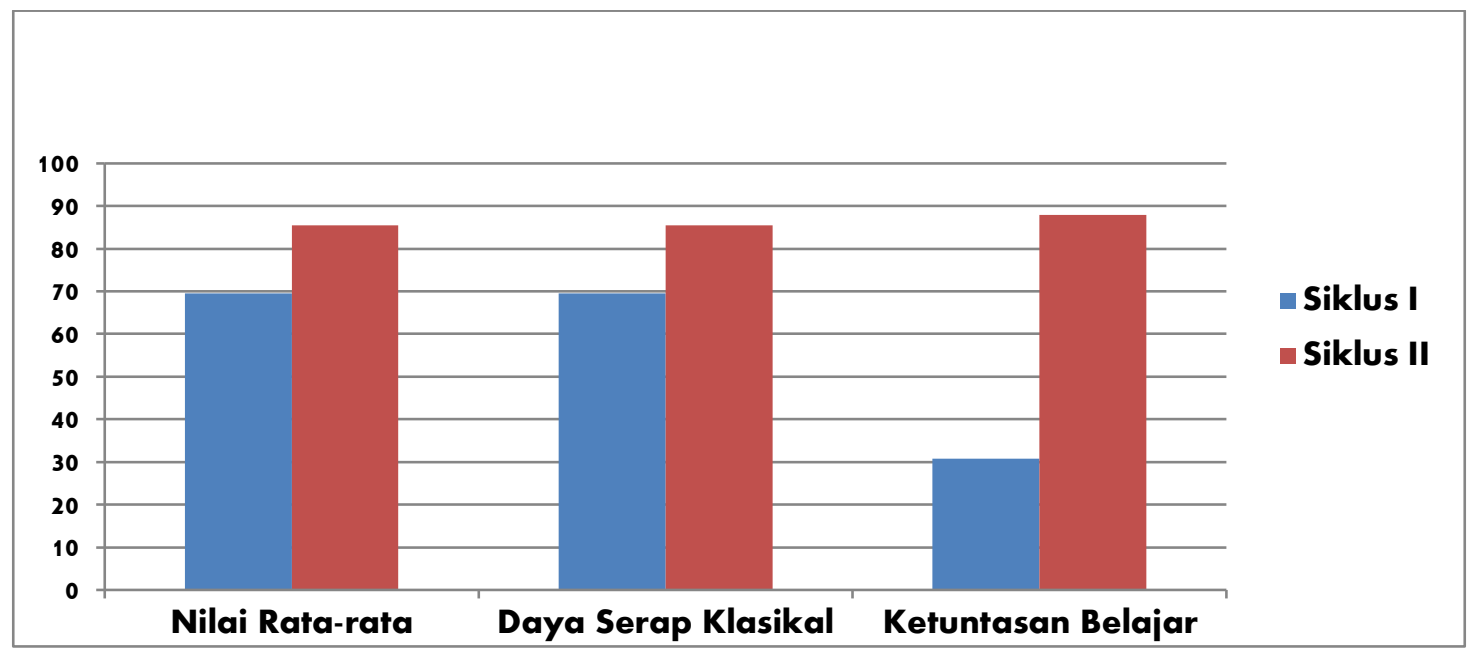

Grafik 4. Peningkatan Hasil Tes Pidato Siklus I dan Siklus II

Dapat disimpulkan bahwa tingkat keberhasilan pada siklus 1 Belum Berhasil sedangkan pada siklus 2 Sudah Berhasil. Jika dilihat dari hasil belajar siswa secara individu ada beberapa siswa yang tetap nilainya, tetapi kebanyakan siswa mengalami peningkatan dan tidak ada yang mengalami penurunan. Hal ini merupakan hasil penelitian yang ditindaklanjuti dengan memperhatikan karakteristik siswa.

\section{KESIMPULAN}

Berdasarkan analisis hasil dan pembahasan yang telah dilakukan di atas, dapat disimpulkan bahwa Kemampuan Berpidato di Depan Kelas pada Siswa Kelas IX A SMP Negeri 5 Kota Bengkulu dengan Menggunakan Metode Pembelajaran Terbalik Mengalami Peningkatan. Hal ini dapat dilihat dari rata-rata nilai yang diperoleh siswa pada tiap siklusnya. Pada siklus I, nilai rata-rata yang diperoleh siswa sebesar 69,53 dan ketuntasan belajar secara klasikal 34,61\% serta daya serap klasikal 69,53\%. Pada siklus 2, nilai rata-rata yang diperoleh siswa sebesar 85,53 dan ketuntasan belajar secara klasikal 88,46\% serta daya serap klasikal 85,53\%. Angka presentase tersebut telah memenuhi batas minimal ketuntasan belajar yang 
telah ditetapkan. Jadi dapat disimpulkan bahwa ketuntasan belajar secara klasikal sudah mencapai hasil yang sangat baik. Dengan metode Pembelajaran Terbalik, dapat meningkatkan aktifitas belajar siswa. Sehingga kegiatan pembelajaran menjadi lebih efektif dan menyenangkan. Penggunaan metode Pembelajaran Terbalik dalam pembelajaran Bahasa Indonesia merupakan salah satu langkah yang dapat dilakukan oleh guru di dalam menyampaikan materi pembelajaran berpidato di depan kelas, sehingga siswa dapat meningkatkan keterampilan berpidato di depan kelas. Melalui kegiatan pembelajaran ini dapat dijadikan sebagai motivasi bagi siswa untuk tetap memotivasi diri dalam meningkatkan keterampilan berpidato, baik di lingkungan sekolah maupun di lingkungan masyarakat. Bagi guru dapat dijadikan sebagai langkah untuk pengembangan diri dalam meningkatkan keprofesionalan guru dalam pembelajaran.

\section{DAFTAR PUSTAKA}

Arikunto S. Suhardjono. (2012). Penelitian Tindakan Kelas. Jakarta: Bumi Aksara.

Candra, Ade dan Febsri S. (2019). Pengaruh Bauran Promosi dan Harga Terhadap Keputusan Pembeli Produk Kosmetik. Kota Padang: Sekolah Tinngi Ilmu Ekonomi KBP.

Darmuki, A. \& Hidayati. (2019). Peningkatan Kemampuan Berbicara Menggunakan Metode Kooperatif Tipe NHT pada Mahasiswa PBSI IKIP PGRI. Bojonegoro Tahun Akademik 2018/2019. Jurnal Pendidikan Edutama Vol. 6 (2) Hal. 9-18.

Ilham, Muhammad \& Wijiati. (2020). Keterampilan Berbicara Sebagai Keterampilan Berbahasa. Lembaga Akademic \& Research Institute: Pasuruan.

Mahardini. (2020). Metode Debat Dalam Peningkatan Keterampilan Berbicara. Universitas Jambi: Jambi.

Muhadi. (2011). Penelitian Tindakan Kelas. Yogyakarta: Shira Media.

Putriyani, P. (2019). Kemempuan Membaca Teks Pidato Siswa Kelas IX i SMP Negeri 3 Palu. Jurnal Bahasa Dan Sastra (51-52)

Sugiyono. (2013). Metode Penelitian Kuantitatif- Kualitatif dan RD. Bandung: Alfabeta.

Tarigan, Henry Guntur, dkk. (2015). Berbicara Sebagai Suatu Keterampilan Berbahasa. Bandung: Angkasa. 